\section{Expression level of DREB gene of local corn cultivars from Kisar Island-Maluku, Indonesia, using quantitative real time polymerase chain reaction}

\author{
Hermalina Sinay, ${ }^{1}$ \\ Estri Laras Arumingtyas ${ }^{2}$ \\ ${ }^{1}$ Biology Education Program, Faculty \\ of Teaching and Education, Pattimura \\ University, Ambon-Maluku; ${ }^{2}$ Biology \\ Department, Faculty of Mathematics \\ and Natural Sciences, Brawijaya \\ University, Malang-East Java, Indonesia
}

\begin{abstract}
The research objective was to determine the expression level of dehydration responsive element binding (DREB) gene of local corn cultivars from Kisar Island Maluku, Indonesia. The study was designed as randomized block design with single factor consist of six local corn cultivars obtained from farmers in Kisar Island and one reference varieties which has been released as a drought-tolerant varieties and obtained from Cereal Crops Research Institute Maros South Sulawesi. Isolation of total RNA from the second leaf after the flag leaf at the 65 days after planting were carried out according to the protocols of the R \& ABlue $^{\mathrm{TM}}$ Total RNA Extraction Kit, and was used as a template for cDNA synthesis. Amplification of cDNA from total RNA was carried out according to the protocol of One-Step Reverse Transcriptase PCR Premix Kit. Real Time-PCR was performed usingcDNA from reverse transcription following the procedures of Real MOD ${ }^{\mathrm{TM}}$ Green Real-Time PCR Master Mix Kit. The real time-PCR data were analyzed using relative quantification method based on the critical point/cycle threshold. The highest DREB gene expression was showed by Deep Yellow local corn cultivar, and the lowest one was showed by Rubby Brown Cob cultivar. The DREB gene expression level of deep yellow local corn cultivar was even higher than Srikandi variety as a reference variety.
\end{abstract}

\section{Introduction}

Drought is one important abiotic factors that may limit the growth and production of crops, especially cereal crops in various places in the world. ${ }^{1-3}$ The response of plants to drought stress can also be observed at the molecular level through the synthesis and expression of genes related to drought resistance. ${ }^{4-6}$ Genes that control plant responses to drought have been identified in many types of crops and one of them is the drought responsive element binding protein (DREB) gene which encodes a transcription factor protein and is associated with the expression of the nature of plant resistance to stresses including drought. ${ }^{7-9}$

$D R E B$ gene is a member of the APETALAe/ethylene-responsive elementbinding protein (AP2/EREB) family. The AP2 family consist of genes that function to encodes a transcription factor protein. $D R E B$ gene encodes a transcription factor protein DREB which involved in the mechanism of plant adaptation to drought. Transcription factor proteins encoded by the genes of a sub-family AP2 has a sustainable domain (conserved domain) AP2/ERF consisting of 50-60 amino acids. The existence of this domain, assist the identification of these proteins. ${ }^{10-16}$

Kisar Island is one area in the district of South West Maluku Regency which has the potential for developping corn. In the development strategy of corn in Maluku, Kisar island determined to be in region I of the development strategy. This determination is based on the high utilization of corn as a staple food by the public, but planted in dry climates. ${ }^{17}$ An exploration and documentation of corn germplasm in the Kisar island was conducted and found that there are seven local cultivars of corn that are specific to that Island namely: i) Rubby Brown Cob cultivar, ii) White Brown Cob cultivar, iii) Red Blood, iv) White, v) Waxy, vi) Early Maturing Yellow, and vii) Deep Yellow cultivar. These local corn cultivars have potential to be developed, because it has an ability to adapt to the local dry environment. ${ }^{18}$

In order to increase the production and to develop a plant as a superior crop, the properties of plants related to its ability to adapt to the environment, especially the environment with limited water availability, absolutely must be known. Some reference was stated that the first step to obtain cultivars tolerant to abiotic stresses such as drought is evaluation and selection of germplasm collection available. ${ }^{19}$ While, another researcher was reported that germplasm can be either local cultivars (landraces), ${ }^{20}$ or can be accession including individual pure lines that has not been tested to determine its properties. ${ }^{21}$

The properties of plants associated with adaptability to limited water availability conditions can be observed in molecular
Corespondence: Hermalina Sinay, Biology Education Program, Faculty of Teaching and Education, Pattimura University, AmbonMaluku 97231, Indonesia.

E-mail: herlinbio@yahoo.co.id

Key words: Expression level; DREB gene; local corn cultivars.

Acknowledgments: this research was a part of first author doctoral research project wich was funded by the Directorate of Higher Education Ministry of Research Technology and Higher Education The Republic of Indonesia. The authors greatly ackowledge for the availability of these funding.

Contributions: HS, performed most of experimental work, data collecting and analyzing, manuscript writing; ELA, supervised experimental work in laboratory, helped correct the paper, perpormed the english language of the paper.

Conflict of interest: the authors declare no potential conflict of interests.

Received for publication: 13 December 2016. Accepted for publication: 12 January 2017.

This work is licensed under a Creative Commons Attribution-NonCommercial 4.0 International License (CC BY-NC 4.0).

(C) Copyright H. Sinay and E. Laras Arumingtyas, 2018 Licensee PAGEPress srl, Italy

International Journal of Plant Biology 2018; 9: 7005 doi:10.4081/pb.2018.7005

level, such as observation of genes involved in adaptation to drought. For the local corn cultivars in Kisar Island, study on the response of the corn cultivars in its natural condition including molecular responses has not been done. The purpose of this study was to determine the level of DREB gene expression on local corn cultivars in Kisar Island Maluku.

\section{Materials and Methods}

In this research, there are two leaf samples. One from the field and one is the control. Control is corn cultivars planted in the normal condition during 30 days (not under drought stress condition) and used to compare gene expression with samples from the field (under drought stress condition). Isolation of total RNA (samples from field) was conducted using the second leaf after flag leaf at the 65 days after planting, while for control using the second leaf from tip at the 30 days after planting.

Isolation of total RNA for both samples 
(from field and control) were carried out according to the protocols of the R\&ABlue $^{\mathrm{TM}}$ Total RNA Extraction Kit (Intron Biotechnology, Seongnam, Korea). The RNA then used as a template for cDNA synthesis according to the protocol of the OneStep ReverseTranscriptase PCR Premix Kit (Intron Biotechnology). A total of $4 \mathrm{~mL}$ reagent, $2 \mathrm{~mL}$ samples of RNA isolated, and $4 \mathrm{~mL}$ of ddH2O was inserted into the thin wall and prepared for cDNA synthesis by reverse-transcriptase PCR reaction.

Reverse transcriptase polymerase chain reaction (PCR) was programmed; it includes reverse transcription reaction at $45^{\circ} \mathrm{C}$ for 30 minutes, and denaturation at $94^{\circ} \mathrm{C}$ for 10 minutes for one cycle. To ensure that the reverse transcription performed successfully, a standard PCR reaction was carried out. Real Time-PCR was performed using the cDNA obtained from the reverse transcription process following the procedure of Real MOD ${ }^{\mathrm{TM}}$ Green RealTime PCR Master Mix Kit (Intron Biotechnology). A total $1 \mu \mathrm{L}$ cDNA plus $1 \mu \mathrm{L} \mathrm{ZmDBP} 2$ forward primer, $1 \mu \mathrm{L}$ primary gene $\mathrm{ZmDBP}_{2}$ reverse primer, $10 \mathrm{~mL}$ Real MOD Real-Time PCR Master Mix Kit, and $5 \mathrm{~mL}$ of Bovine Serum Albumine (400 $\mathrm{ng} / \mathrm{mL}$ ) were inserted into cappilary tube 20 $\mathrm{mL}$ volume, and prepared for the real timePCR reactions. Real time-PCR was performed using Light Cycler Real Time PCR Instrument (Roche, Basel, Switzerland) with the program as shown in Table 1.

The real time-PCR data were analyzed using relative quantitative methods based on the critical point/cycle threshold $\left(\mathrm{C}_{\mathrm{P}} / \mathrm{C}_{\mathrm{T}}\right)$ between the target gene (gene $D R E B$ ) normalized to the housekeeping genes $\beta$-actin as a reference gene. ${ }^{22} D R E B$ gene expression in samples in the field, expressed of how many times compared with control. ${ }^{23}$

\section{Results and Discussion}

The results of experiments for sample from the field (Figure 1A) and the control (Figure 1B) both show that the reverse transcriptase-PCR were successfully performed the cDNA, and the resulted $150 \mathrm{bp}$ cDNA was in accordance in length with the product of ZmDBP2 primer. The success of cDNA synthesis process is influenced by the purity of RNA obtained. Factors that influence the success of cDNA synthesis is the purity of RNA template (free of contaminant such as proteins, polysaccharides, and DNA) and RNA integrity. ${ }^{23}$ cDNA obtained was used for real time PCR process to measure the mRNA expression level of $D R E B$ gene. Real Time-PCR was performed on cDNA samples from reverse transcriptase PCR experiment results in the field and a control sample that has been done before. The results of agarose gel electrophoresis of cDNA in real time-PCR showed that the DREB gene also successfully amplified with $150 \mathrm{bp}$ of PCR product (Figure 2). mRNA expression levels of the $D R E B$ gene were quantitatively analyzed based on theresults of real time PCR. Quantitative analysis is based on the calculation of the value of cycle threshold $\left(\mathrm{C}_{\mathrm{T}}\right)$. mRNA expression of the $D R E B$ gene levels were analyzed by comparing the $C_{T}$ value of the target gene normalized with housekeeping gene ( $\beta$-actyn gene). $C_{\mathrm{T}}$ value data of the target gene (DREB gene), and the reference gene ( $\beta$-actin gene) as house keeping genes in the sample results of experiments in the fieldand control samples (Figure 3).

Based on Figure 3, it can be seen that the $\mathrm{C}_{\mathrm{T}}$ value of targeted gene and reference gene were vary on both control and sample from field. There are cultivars with high value of $\mathrm{C}_{\mathrm{T}}$ on targeted gene, and low on reference gene. Indeed, there are low value of $\mathrm{C}_{\mathrm{T}}$ level on targeted gene, but show high level of $\mathrm{C}_{\mathrm{T}}$ on reference gene. $\mathrm{C}_{\mathrm{T}}$ value is the value which show the amplification cycle when fluorescent signal overcome the threshold and denote by the increasing of amplicon number. By using relative quantification based on the Livak Method the expression level was done and can be seen in Table 2.

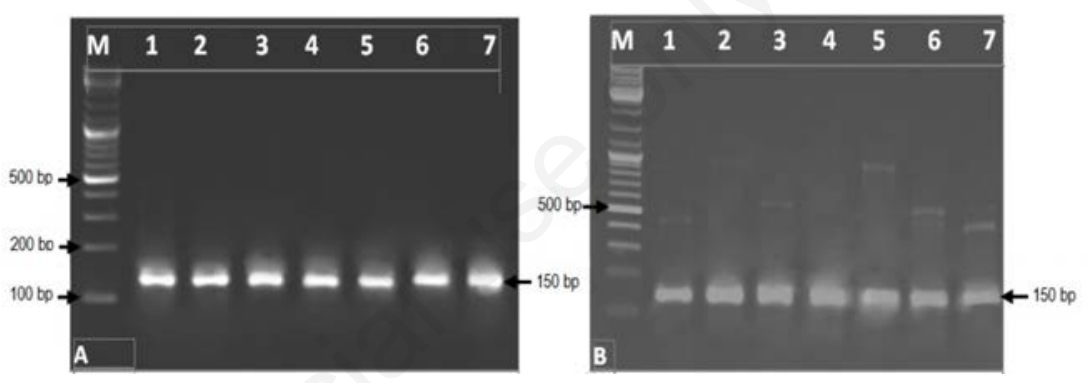

Figure 1. Result of polymerase chain reaction of cDNA amplification with $\mathrm{ZmDBP2}$ primer visualized by using electrophoresis gel agarose. A) Sample from the field, B) control. M: Marker (1000 bp), 1: Rubby Brown Cob, 2: Red Blood, 3: Waxy, 4: Early Maturing Yellow, 5: Deep Yellow, 6: White, 7: Srikandi (reference variety).

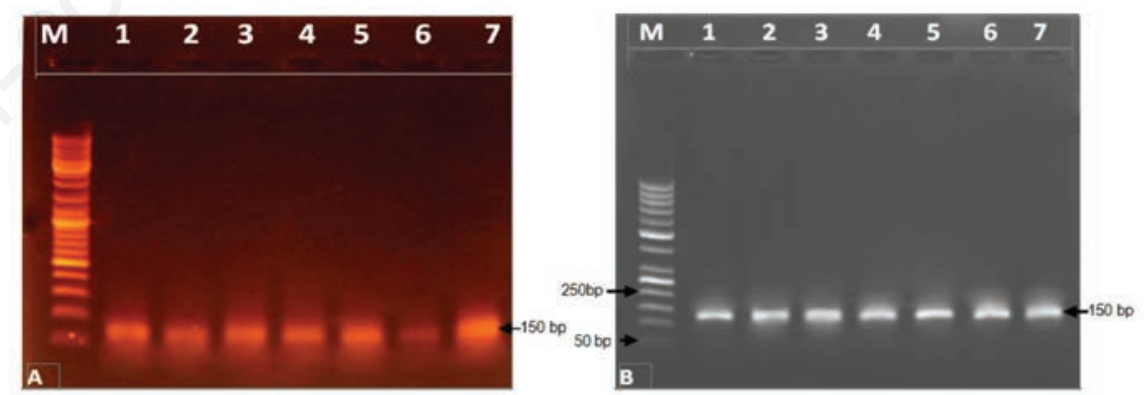

Figure 2. Electrophoresis gel agarose of cDNA real time polymerase chain reaction with $\mathrm{ZmDBP2}$ primer. A) Sample from the field, B) control. M: Marker (1000 bp), 1: Rubby Brown Cob, 2: Red Blood, 3: Waxy, 4: Early Maturing Yellow, 5: Deep Yellow, 6: White, 7: Srikandi (reference variety).

Table 1. Program for real time polymerase chain reaction.

\begin{tabular}{lccc} 
Program & Time & Temperature, ${ }^{\circ} \mathrm{C}$ & No. cycle \\
Pre-denaturation & $30 \mathrm{sec}$ & 95 & 1 \\
Denaturation & $15 \mathrm{sec}$ & 95 & 35 \\
\hline Annealing & $1 \mathrm{~min}$ & 53 & 35 \\
Elongation & $1 \mathrm{~min}$ & 50 & 35 \\
\hline Cooling & $3 \mathrm{~min}$ & 37 & 1 \\
\hline
\end{tabular}


Table 2. Expression level of mRNA in DREB gene.

\begin{tabular}{|c|c|c|}
\hline Cultivars & Expression level & Information \\
\hline Rubby Brown Cob & 4.14 & mRNA of the $D R E B$ gene of sample from the field was expressed 4.1 times than the control \\
\hline Red Blood & 183.54 & mRNA of the $D R E B$ gene of sample from the field was expressed 183.54 times than the control \\
\hline Waxy & 64.44 & mRNA of the $D R E B$ gene of sample from the field was expressed 64.44 times than the control \\
\hline Early Maturing Yellow & 29.446 & mRNA of the $D R E B$ gene of sample from the field was expressed 29.446 times than the control \\
\hline Deep Yellow & 962.071 & mRNA of the $D R E B$ gene of sample from the field was expressed 962.071 times than the control \\
\hline White & 843.3572 & mRNA of the $D R E B$ gene of sample from the field was expressed 843.3572 times than the control \\
\hline Srikandi & 57.28 & mRNA of the $D R E B$ gene of sample from the field was expressed 57.28 times than the control \\
\hline
\end{tabular}

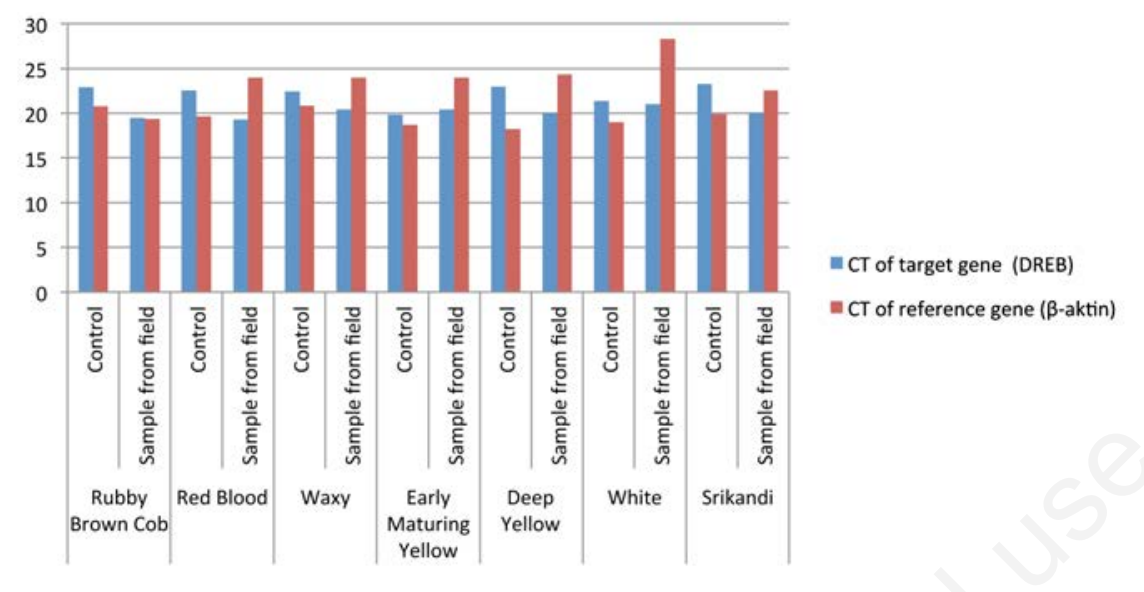

Figure 3. Cycle threshold value of target and reference gene from corn cultivars (control and sample from the field) resulting from real time polymerase chain reaction.

\section{Conclusions}

When compared with control, the $D R E B$ gene of local cultivars and reference variety show a high level of gene expression till hundred times. This is in line with the statement of Silvera et al. ${ }^{25}$ that plant which adapt to drought environment, their gene that control plant traits related to drought will higher expressed. The high level of gene expression of corn cultivars in drought condition shows that plant has molecular mechanism to copy to, by induction and expression of some gene related to plant defense against drought condition. The induction and expression of some gene allow the plant to live and also develop or growth during drought. Even though all cultivars show high level of gene expression, but the highest level of gene expression was showed by Deep Yellow Local Cultivar. This is means that Deep Yellow local cultivars is the most tolerant or the most adaptable of local cultivars to the drought environment condition in Kisar Island. According to $\mathrm{Hu}$ et al. ${ }^{26}$ rice growth on drought condition, it was showed the high level of gene expression, especially for reg- ulatory gene, and this can increase the tolerance of that plant to drought. As same Silvera et $a l .{ }^{25}$ that tolerant rice varieties has high expression of gene that control plant mechanism related to drought. Based on the result, it can be conclude that the expression level of DREB gene was highest in the Deep Yellow corn cultivar and the lowest one obtained by Rubby Brown Cob cultivar.

\section{References}

1. Mafakheri A, Siosemardeh A, Bahramnejad B, et al. Effect of drought stress on yield, proline and chlorophyll contents in three chickpea cultivars. Aust J Crop Sci 2010;8:580-5.

2. Sharada P, Naik GR. Physiological and biochemical responses of groundnut genotypes to drought stress. Wrld J Sci Technol 2011;11:60-6.

3. Bhardwaj J, Yadav, SK. Comparative study on biochemical parameters and antioxidant enzymes in a drought tolerance and a sensitive variety of
Horsegram (Macrotylomauniflorum) under drought stress. Am J Plant Physiol 2012;1:17-29.

4. Ortiz R, Iwanaga M, Reynolds MP, et al. Overview on crop genetic engineering for drought prone environments. ICRISAT 2007;1:1-30.

5. Barros P, Saibo N, Martins M, et al. Identification of candidate genes involved in the response to biotic and abiotic stress in Almond. Options Mediterraneennes 2010;94:87-94.

6. Liang-Zhou M, Tao-Ma J, Feng-Pang J, et al. Regulation of plant stress response by dehydration responsive element binding (DREB) transcription factors. Afr J Biotechnol 2010;54:925-7.

7. Shahrokhabadi K, Afshari RT, Alizade $\mathrm{H}$, et al. Identification of DREB homologous genes in bread wheat via CODEHOP PCR primer design. Pak J Biol Sci 2008;16:1979-86.

8. Lopato S, Langridge P. Engineering stress tolerance in cereals using DREB/CBF genes: outcomes, problems, and perspective. 2011. ISB News Report

9. Hemalatha N, Rajesh M, Narayanan, NK. Genome wide analysis of putative ERF and DREB gene families in indica rice (O. sativa L. subsp. Indica). Int J Machine Learn Comput 2012;2:556-9.

10. Saleh A, Pagés M. Plant AP2/ERF transcription factors. Genetika 2003;1:37508 i.

11. Andeani JK, Mohsenzadeh S, Mohabatkar H. Isolation and characterization of partial DREB gene from four Iranian Triticum aestivum cultivars. Wrld J Agric Sci 2009;5:561-6.

12. Sharoni AM, Nuruzzaman M, Satoh K, et al. Gene structures, classification and expression models of the AP2/EREBP transcription factor family in rice. Plant Cell Physiol 2011;2:344-60.

13. Akhtar M, Jaiswal A, Taj G, et al. DREB1/CBF transcription factors: their structure, function and role in abiotic stress tolerance in plants. J Genet 2012;3:385-95. 
14. Chen Y, Yang J, Wang Z, et al. Gene structures, classification, and expression models of the DREB transcription factor subfamily in Populus trichocarpa. Sci World J 2015;1-12.

15. Jadhao KR, Samal KC, Pradhan SK, Rout GR. Studies on molecular characterization of DREB gene in indica rice (Oryza sativa L.). Hereditary Genet 2014;3:133.

16. Zandkarimi H, Ebadi A, Salami SA, et al. Analyzing the expression profile of AREB/ABF and DREB/CBF genes under drought and salinity stresses in grape (Vitis vinifera L.). PLoS One 2015;7:e0134288.

17. Susanto AN, Sirappa MP. [Characterization and data availability of land resources in small islands for agricultural development and planning in Maluku]. Jurnal Litbang Pertanian 2007;2:41-53. [Article in Indonesian].

18. Alfons JB, Pesireron M, Rieuwpassa AJ, et al. [Study on Increasing and
Productivity of Traditional Food Plant in Maluku]. Ambon Maluku: Institute of Agriculture and Technology 2003. [Article in Indonesian].

19. Adiwilaga K, Hidayat S. [Using of germplasm by biotechnology to increase Pemanfaatan plasma nutfahmelaluibioteknologidalam agricultural production]. Biotechnology Part of Monagro Kimia. 2006. [Article in Indonesian].

20. Amzeri A. [Performance of five local corn in Madura]. Agrovigor 2009;1:2330. [Article in Indonesian].

21. Juhriah, Baharuddin Y, Musa, Pabendon MB. [Phenotypic performance of local corn germplasm in West Sulawesi and Centered Sulawesi with corn from CYMMIT for provit-A corn selection]. Faculty of Science Makassar University. 2011. (Article in Indonesian].

22. Livak KJ, Schmittgen TD. Analysis of relative gene expression data using realtime quantitative PCR and the 2_ $\Delta \Delta \mathrm{CT}$ method method. Methods 2001;25:4028.

23. Wang CT, Yang Q, Tao Wang C. Isolation and functional characterization of $\mathrm{ZmDBP} 2$ encoding a dehydration-responsive element-binding protein in Zea mays. Plant Mol Biol Rep 2011;29:60-8.

24. Wang X, Young WS. Rapid amplification of cDNA ends. In: Bartlett JMS, Stirling D. Methods in molecular biology. Vol 226. PCR Protocols. 2nd ed. Totowa: Humana Press Inc.; 2003.

25. Silvera RDD, Abreu FRM, Mamidi S, et al. Expression of drought tolerance genes in tropical upland rice cultivars (Oryza sativa). Genet Mol Res 2015;3:8181-200.

26. $\mathrm{Hu} \mathrm{H}$, Dai M, Yao J, et al. Overexpressing a NAM, ATAF, and CUC (NAC) transcription factor enhances drought resistance and salt tolerance in rice. PNAS 2006;35:12987-92. 